\title{
IMPACT OF TOOTH LOCATION ON THE TREATMENT OF MULTIPLE GINGIVAL RECESSIONS WITH CONNECTIVE TISSUE GRAFT ASSOCIATED WITH A CORONALLY ADVANCED FLAP
}

\begin{abstract}
Objectives: Coronally advance flap (CAF) effectiveness has been extensively evaluated, but little information is available regarding the effect of tooth position. This study aimed to evaluate the influence of tooth location on the outcomes of CAF with subepithelial connective tissue graft (SCTG) in the treatment of gingival recessions defects (GRs).
\end{abstract}

Materials and Methods: Nineteen patients with a mean age of $36.3 \pm 7.6$ years (11women, 8 men), each contributing Miller Class I and II GRs, were selected. Forty-four defects were treated with a combination of a CAF and a SCTG. Gingival recession depth (RD), gingival recession width (RW), probing depth (PD), and clinical attachment level (CAL) were recorded at baseline and 12 months postoperatively

Results: The mean root coverage from baseline to 1year post-surgery was 89 $\%$ for the maxillary GRs and $68 \%$ for the mandibular GRs. RD and RW were decreased in both groups from baseline to 12 months $(p<0.001)$, but the difference between groups was not statistically significant. Both treatments showed satisfactory root coverage esthetic scores (maxillary teeth $8.2 \pm 1.3$ and in mandibular teeth $7.6 \pm 1.1$ ).

Conclusions: The findings of the current study have shown that the CAF is an effective procedure for the treatment of multible GRs. Besides, the two groups (maxillary and mandibular GRs) showed similar significant improvements from baseline to 12 months evaluations.

Keywords: Connective tissue, gingival recession, surgical flaps, tooth.
*Nezahat Arzu Kayar ${ }^{1}$

Zeliha Aytekin ${ }^{1}$

ORCID IDs of the authors:

N.A.K. 0000-0002-2325-2900

Z.A. $\quad 0000-0002-6743-1994$

${ }^{1}$ Department of Periodontology, Faculty of Dentistry, Akdeniz University, Antalya, Turkey.

Accepted : : 11.04.2021

How to Cite: Kayar NA, Aytekin Z. Impact of Tooth Location on the Treatment hf Multible Gingival Recessions with Connective Tissue Graft Associated with a Coronally Advanced Flap. Cumhuriyet Dent J 2021;24:2:.

*Corresponding Author:

Akdeniz Üniversitesi Dişhekimliği Fakültesi, Periodontoloji Bölümü, 07058 Antalya/Turkey.

Phone: +905325759333 E-mail: narzu@hotmail.com 


\section{INTRODUCTION}

Gingival recession (GR) is defined as the opening of the root surface to the oral cavity by the displacement of the gingiva towards the apical of the cementoenamel junction. ${ }^{1,2}$ This condition affects a large part of the population, regardless of the standard of oral hygiene. ${ }^{3}$ The etiology of GR in today's dentistry is multifactorial, It is thought that the effect of more than one factor at the same time and their cumulative effects lead to GRs. ${ }^{4}$ GRs could be related to a large variety of predisposing precipitating and predisposing factors: plaqueinduced gingival diseases, ${ }^{5}$ aberrant frena, ${ }^{5}$ traumatic toothbrush, ${ }^{6}$ tooth malposition, ${ }^{3}$ orthodontic treatment, ${ }^{7}$ improper flossing ${ }^{8}$ and iatrogenic. Aesthetic problems, dentin hypersensitivity, and accompanying with a carious or noncarious cervical lesion are the major indications for the treatment of these GRs and have been extensively documented in the literature that GR can be treated satisfactorily with several root coverage procedures (RCP). ${ }^{9-11}$

Several alternative substitutes to connective tissue have been tested in overcoming to eliminate the problems associated with a second surgical site $^{12-14}$ but meta-analyzes have shown that subepithelial connective tissue grafts (SCTG) can be accepted as the gold standard procedure for GR treatment. ${ }^{10,15,16}$ Consensus opinion on the treatment of GR clearly shows that SCTG based procedures lead to the best clinical results because of their excellent percentages of root coverage and the enhanced possibility of complete root coverage, as well as significant increase in keratinized tissue width when comprised with most of the other procedures. ${ }^{10,17}$

Due to the high success rate in root closure from past to present, the most preferred one is CAF surgery. ${ }^{18,19}$ This technique aims to cover the root surface based on the principle of sliding the gingiva to the coronal direction at the apical of the GR. ${ }^{20}$ The predictable closure of multiple GRs still represents one of the most challenging situations in aesthetic plastic periodontal surgery. ${ }^{21}$ Anatomical variations such as the larger avascular surface due to the size of the surgical area, weaker blood supply, the position of the tooth roots, shallow vestibules, and differences in gingival recessions depth are the factors that make the surgery and wound healing difficult. ${ }^{22,23}$

Given the effects of tooth location on the results of root coverage techniques, it is of foremost importance to understand the true probability of achieving a complete root coverage after treatment with SCTG+CAF in maxillary and mandibular defects. Although, there are several studies related to the effect of SCTGs for the treatment of localized GRs ${ }^{24-26}$, there is limited information regarding the use of subepithelial connective tissue graft plus coronally advanced flap (SCTG+CAF) for the treatment of multiple GRs. Considering the effects of the depth of the vestibular fornix, flap tensions, flap thickness, and mucogingival phenotypes on the results of periodontal plastic surgery, the hypothesis of the study stated that the percentage of root coverage is greater in the maxilla than mandibula in the treatment of multiple gingival recessions with $\mathrm{CAF}+\mathrm{SCTG}$. Thus, this retrospective study aimed to evaluate the clinical outcomes of SCTG+CAF in the treatment of multiple GRs concerning the tooth location

\section{MATERIAL AND METHOD}

Written informed consent was obtained from all subjects included in the surgical treatment with an agreement to use their data for the clinical trials in accordance with the Helsinki Declaration 1975 as revised 2000. The study was approved by the Clinical Research Ethics Board of Akdeniz University Faculty of Medicine (70904504/745).

This study was carried out on 44 GRs in 19 patients (11 females and 8 males, aged 31-43 years) Data were collected by evaluation of records of patients treated with SCTG+CAF for GRs in Akdeniz University Faculty of Dentistry Department of Periodontology Antalya Turkey, between 2018 and 2019 and controlled 12 months follow-up period.

\section{Clinical measurements:}

Demographic details, age and sex were recorded. The following clinical measurements were performed at baseline and 12 months follow-up postoperatively by a single calibrated, blinded 
examiner (ZA) using a periodontal probe (UNC 15 Periodontal probe; Hu-Friedy, Leimen, Germany): 1)plaque index $\left.(\mathrm{PI})^{27}, 2\right)$ gingival index (GI), ${ }^{28} 3$ ) Probing depth (PD), measured from the marginal gingiva to the bottom of the gingival sulcus; 4) Clinical attachment level (CAL), recorded from the CEJ to the bottom of the gingival sulcus; 5) Recession depth (RD), measured from the CEJ to the marginal gingiva. ${ }^{29}$ 6) Recession width (RW): measured from one border of the defect to another at the CEJ. ${ }^{30}$

\section{Esthetic evaluation:}

After 12 months, experienced independent specialist (ZA) evaluated the esthetic outcome of surgery. Root coverage esthetic score (RES) system assessed five variables as follows: 1) gingival margin $(\mathrm{GM})$ level: zero-point = failure of root coverage; 3 point $=$ partial root coverage; and 6 point $=$ complete root coverage; 2 ) marginal tissue contour: zero-point $=$ irregular gingival margin; 1 point $=$ proper marginal contour; 3 ) soft tissue texture: zero-point $=$ presence of scar of keloid-like appearance; 1 point= absence of scar; 4) Mucogingival Junction (MGJ) alignment: zeropoint= MGJ not aligned with MGJ on adjacent teeth; 1 point= MGJ aligned with MGJ on adjacent teeth; and 5) gingival color: zero-point $=$ color of tissue varies from gingival color on adjacent teeth; 1 point=normal color and integration with adjacent soft tissues. The excellent RES score was 10 point and worst was zero point, which equivalent to unsuccessful root coverage.

\section{Initial therapy:}

Before surgery, all subjects received oral hygiene instructions to modify their habits associated with the etiology of GRs. Phase I periodontal therapy (consisting of ultrasonic scaling and polishing) was performed.

\section{Surgical technique:}

Both surgical operations have been conducted by one operator with plastic periodontal surgery clinical experience (NAK). The envelope type of CAF technique was performed which was proposed by Zucchelli and De Sanctis ${ }^{31}$ in 2000. After local anesthesia, a horizontal incision was made to involve one more tooth on each border of the GRs related teeth to be operated for easing the coronal repositioning of the gingival tissue to the mucogingival junction. The horizontal incision of the envelope flap was composed of oblique interdental submarginal incisions to design the external surgical papilla (SP), incisions which continued with the sulcular incision at the GRs defects. Every single SP was displaced concerning the anatomic papilla by the oblique interdental submarginal incisions. Briefly, the SP, which are mesial to the midline of the flap were displaced more distally and apically, while the SP which are distal to the midline of the flap was shifted in a more mesial and apical position. Split thickness approach of SP was done till the sulcular area, incisions were carried out keeping the scalpel parallel to the root surface. The full-thickness flap of the gingival tissue under the exposed root was dissected apical position to exposed 3-4 mm alveolar bone and the fragment of the flap critical for root coverage with more thickness was prepared. At last, the most apical fragment of the flap was dissected in a split-thickness approach to facilitate the coronal shift of the gingival tissue. The root surfaces were planed gently with periodontal curettes. Facial gingival tissue of the remaining interdental papillae was deepithelialized to create connective tissue beds to which the SPs were sutured. A sharp dissection into the vestibular sulcus mucosa was made to prevent muscle tension. The SCTG was harvested from the palate between the canine and the 1st molar area using a surgical knife. The SCTG, about 1 to $1.5 \mathrm{~mm}$ thick, was positioned in the recipient site to cover the exposed root surface. Absorbable (Coated Vicryl, Ethicon, Johnson\&Jonhnso, Belgium) subperiosteal sutures were used to secure the graft in the recipient site; then the envelop type CAF flap was shifted coronally and sutured using 5-0 propylene sutures (Ethicon, Johnson and Johnson Intl, St. Stevens, Woluwe, Belgium) to cover the SCTG completely. Sling sutures were carried out to achieve a complete adaptation of the flap on the exposed root surfaces and to fix each SP over the interdental recipient site.

\section{Post-Surgical Protocol}

Analgesics (flurbiprofen 100mg, two times daily) and antibiotics (amoxicillin, 1g, two times daily) were prescribed for all patients after the surgical 
procedure. The patients were told to rinse their mouths twice a day with a mouthwash containing $0.12 \%$ Chlorhexidine the day after the procedure. It was explained that brushing the areas with avoiding any mechanical trauma. After 10 days, the sutures in the surgical areas were removed.

According to the standard formula, percentages of root coverage [ $(100 \times($ baseline recession depth -1 year follow-up recession depth)) /baseline recession] and full root coverage have been determined. ${ }^{12}$ The patients were called for postoperative controls at the $1^{\text {st }}$ and $12^{\text {th }}$ months to evaluate the surgical site, professionally perform supragingival cleaning, and explain oral hygiene procedures.

\section{Statistical analysis}

The sample size was calculated with an assumed power of $85 \%$ to detect a minimum clinically significant difference in RD of $1 \mathrm{~mm}$ (using $=0.05$ ) and a standard deviation of $1.1 \mathrm{~mm}$. Descriptive statistics were expressed as mean \pm standard deviation. The normality of the data was tested by using a Shapiro-Wilk test. All data were not normally distributed and the Wilcoxon test was used to detect significant differences within and between each group before and after therapy. At baseline, the statistical significance of differences in clinical parameters and percentages of root coverage between two groups was analyzed using the Mann-Whitney $U$ test. The baseline clinical periodontal parameters were accepted covariates and Univariant analysis was used to evaluate differences between study groups.

\section{RESULTS}

Nineteen patients (mean age 36.3 $\pm 7.6,31-43$ years, 11 females and 8 males) completed all examinations throughout 12 months. In these patients, 44 Miller Class I or II recession-type defects were treated. All recipient sites in both groups were uneventfully healed concerning the postoperative period.

There was no statistically significant difference between the for patients with mandibular GRs and maxillar GRs in gender at baseline. (Table 1).

Table 1: Clinical measurements at baseline and 1 year post-surgery.

\begin{tabular}{|c|c|c|c|}
\hline & $\begin{array}{c}\text { Baseline } \\
\text { Mean } \pm \text { SD }\end{array}$ & $\begin{array}{c}1 \text { year } \\
\text { Mean } \pm \text { SD }\end{array}$ & $\begin{array}{c}\text { Baseline versus } \\
1 \text { year } \\
p \text {-value }\end{array}$ \\
\hline PI maxillary teeth & $0.77 \pm 0.43$ & $0.32 \pm 0.42$ & 0.527 \\
\hline PI mandibular teeth & $0.59 \pm 0.50$ & $0.50 \pm 0.50$ & 0.180 \\
\hline$p$-value & 0.075 & 0.132 & 年 \\
\hline GI maxillary teeth & $0.75 \pm 0.46$ & $0.71 \pm 0.49$ & $0 . \overline{2} 02$ \\
\hline GI CAF mandibular teeth & $0.25 \pm 0.46$ & $0.57 \pm 0.53$ & 0.414 \\
\hline$p$-value & 0.201 & 0.225 & - \\
\hline PD (mm) maxillary teeth & $1.75 \pm 1.03$ & $1.74 \pm 0.64$ & $0 . \overline{137}$ \\
\hline PD (mm) mandibular teeth & $1.71 \pm 0.49$ & $1.28 \pm 0.48$ & 0.206 \\
\hline$p$-value & 0.431 & 0.647 & - \\
\hline CAL (mm) maxillary teeth & $4.87 \pm 2.23$ & $2.25 \pm 1.03$ & $<0.001$ \\
\hline CAL (mm) mandibular teeth & $4.00 \pm 0.81$ & $2.0 \pm 1.41$ & $<0.001$ \\
\hline$p$-value & 0.189 & 0.382 & - \\
\hline $\mathrm{RD}(\mathrm{mm})$ maxillary teeth & $3.12 \pm 1.95$ & $0.37 \pm 0.74$ & $<0.001$ \\
\hline $\mathrm{RD}(\mathrm{mm})$ mandibular teeth & $2.28 \pm 0.95$ & $0.71 \pm 0.95$ & $<0.001$ \\
\hline$p$-value & 0.165 & 0.767 & - \\
\hline RW (mm) maxillary teeth & $4.37 \pm 1.41$ & $0.75 \pm 1.38$ & $<0 . \overline{001}$ \\
\hline $\mathrm{RW}(\mathrm{mm})$ mandibular teeth & $3.14 \pm 0.89$ & $1.28 \pm 1.70$ & $<0.001$ \\
\hline$p$-value & 0.010 & 0.455 & _ \\
\hline
\end{tabular}

The average percentage of root coverage was $76 \%$ for the mandibular GRs and $93 \%$ for the maxillary GRs. Moreover, the percentage of sites with complete root coverage was $57 \%$ and $76 \%$ respectively (Figure 1). The professional esthetic evaluation recorded the two groups presented similar RES after 12 months (in maxillary teeth $8.2 \pm$ and in mandibular teeth 7.6 \pm 1.1 ). 


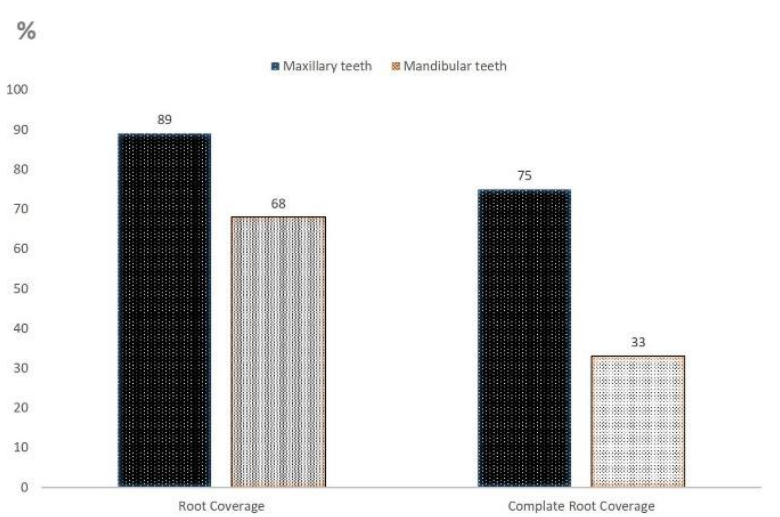

Figure 1. The percentage of root coverage and the percentage of root surfaces showing complete root coverage 1 year.

For patients with mandibular GRs, mean RD decreased from $2.28 \pm 0.95 \mathrm{~mm}$ to $0.71 \pm 0.95 \mathrm{~mm}$, mean RW decreased from $3.14 \pm 0.89 \mathrm{~mm}$ to $1.28 \pm 1.7 \mathrm{~mm}$, and mean CAL decreased from $4 \pm 0.81 \mathrm{~mm}$ to $2 \pm 1.41 \mathrm{~mm}$ (Table 1 ). For patients with maxillary GRs, mean RD decreased from $3.12 \pm 1.95 \mathrm{~mm}$ to $0.37 \pm 0.74 \mathrm{~mm}$, mean $\mathrm{RW}$ decreased from $4.37 \pm 1.41 \mathrm{~mm}$ to $0.75 \pm 1.38 \mathrm{~mm}$, and mean CAL decreased from $4.87 \pm 2.23 \mathrm{~mm}$ to $2.25 \pm 1.03 \mathrm{~mm}$. (Table 1). For both groups, statistically significant improvements were found for RD, RW, CAL from baseline to 12 months $(\mathrm{P}<0.05)($ Table 1$)$.

Differences between patients with maxillary or mandibular GRs at baseline and 12 months follow-up were presented in Table1. Between groups, no statistically significant differences were found in baseline measurements. $(\mathrm{P}>0.05)$ Similarly, the differences between groups at the 12month follow-up were not found statistically significant for all parameters $(\mathrm{P}>0.05)$. (Figure 2 and 3)

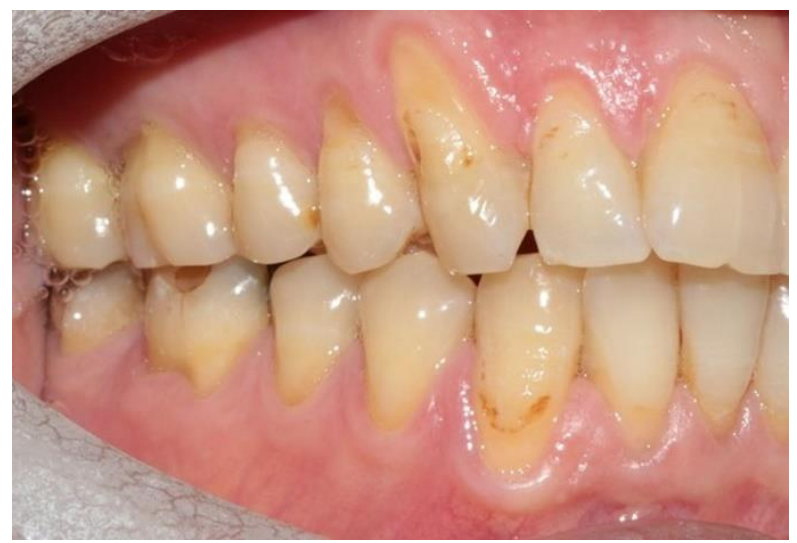

Figure 2: Multiple gingival recession treatment of the maxillary lateral incisor, canine, first premolar and mandibular lateral incisor, canine, first premolar with CAF. a. Preoperative view of recession,

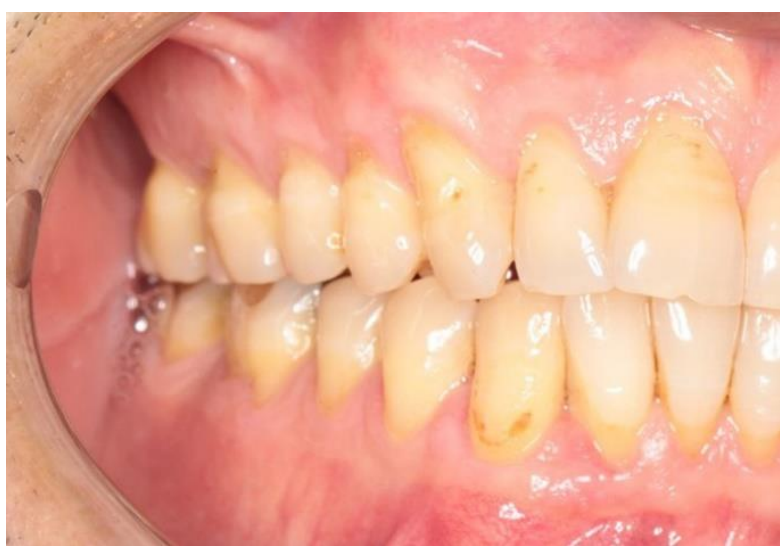

Figure 2b. 12 months postoperative

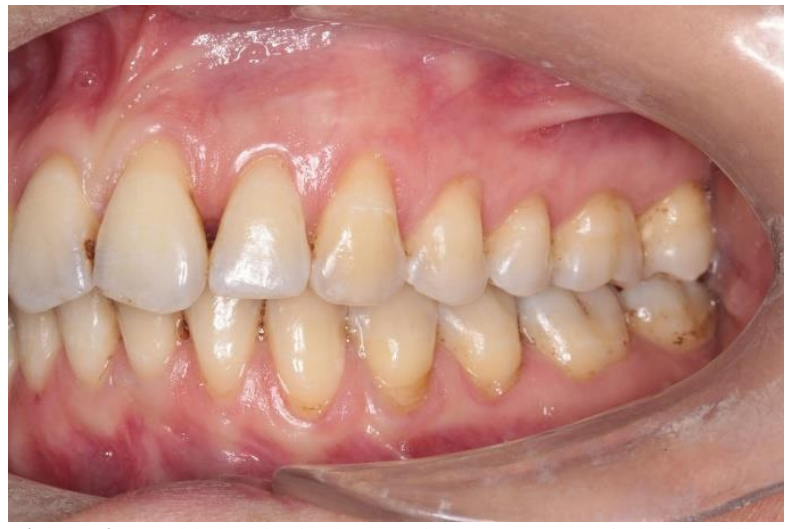

Figure 3: Multiple gingival recession treatment of the maxillary lateral incisor, canine, first premolar and mandibular lateral incisor, canine, first premolar, second premolar with CAF+ SCTG. a. Preoperative view of recession,

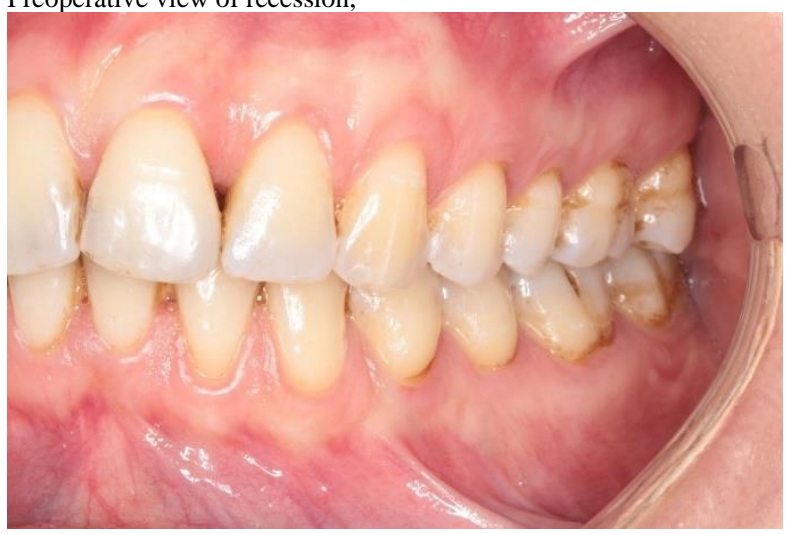

Figure 3b. 12 months postoperative.

\section{DISCUSSION}

The combination of CAF surgery with a subepithelial connective tissue graft was found to be a successful treatment to cover multiple GRs in the current study. A significant improvement in all clinical parameters was observed when the 12 months measurements were compared to the baseline values. While the mean root coverage was $89 \%$ in maxillar GRs and $68 \%$ in mandibular GRs at the postoperative results from the beginning to the last 12 months, full root coverage was obtained in $75 \%$ in maxillar GRs and $33 \%$ in mandibular GRs. 
CAF therapy alone provides an average root coverage of 55-91\% and is still a viable option when it comes to treating GRs. ${ }^{15}$ The results of the present study seem to be similar to the values published by da Silva et al. ${ }^{32}$ and Jepsen et al. ${ }^{33}$ after treatment of the GRs with CAF+SCTG (75.3 and $72.0 \%$, respectively). In this study, multiple GRs in the maxillary and mandibular teeth were included and the root coverage percentage was $72.2 \%$. This percentage was detected as $89 \%$ in maxillar GRs and $68 \%$ in mandibular GRs. Evidence in the published literature has shown that the CAF + SCTG combination is the most effective and predictable surgical procedure for closing GRs defects.

The percentage of sites with complete root coverage was $33 \%$ for the mandibular sites and 75\% for the maxillary sites These data lower than those reported by de Sanctis et al. ${ }^{34} \mathrm{CAF}+\mathrm{SCTG}$ for mandibular recessions. Moreover, this data similar to published by Zucchelli et al ${ }^{29}$ for maxillary teeth. In this study, full root coverage was obtained in $22(50 \%)$ of the 44 GR regions. Full root coverage could not be achieved in posterior teeth, possibly associated with short papilla.

The results of previous studies agree with the findings of a significant increase in CAL and a nonsignificant difference in PD. ${ }^{31,34}$ Through a combination of epithelial down growth and connective tissue attachment, these findings are associated with the graft attachment to the root surface. ${ }^{35}$

The CAF approach was not used with vertical incisions in this study because it was proposed that better clinical results could be obtained by improved vascularization. ${ }^{29}$ The preservation of major gingival vessels within the flap, histologically demonstrated by Mormann, increases the nutrition of the graft. ${ }^{36}$ To our knowledge no studies are comparing the results of the treatment of an GRs of maxillary and mandibular defects without vertical releasing incisions.

Although this $\mathrm{CAF}+\mathrm{SCTG}$ procedure appeared to be more effective for the maxillary than mandibular multiple recession defects, there was no statistically significant difference.
Therefore, further studies with different flap designs will give an idea to clinicians.

\section{CONCLUSIONS}

Combination of the CAF surgery and SGTG was found to be as an efficient procedure to cover multiple GR defects. Much research is needed to increase the effectiveness of this CAF and SCTG procedure, especially in multiple GRs in the mandibular regions. More long-term studies with larger sample sizes are needed to evaluate the efficacy of these techniques

\section{CONFLICTS OF INTEREST STATEMENT}

The author declares no conflict of interest in this study.

$\ddot{O} Z$

Koronal Pozisyone Flep ile İlişskili Bă̆ Dokusu Grefti ile Çoklu Dişeti Çekilmelerinin Tedavisinde Diş Konumunun Etkisi

Amaçlar: Koronale pozisyone flep (KPF) etkinliği kapsamll bir şekilde değerlendirilmiştir, ancak diş pozisyonunun etkisine ilişskin çok az bilgi mevcuttur. Bu çalışma, dişeti çekilme defektlerinin (DÇ) tedavisinde subepitelyal bağ dokusu grefti (SBDG) ile KPF'nin sonuçlarına diş lokasyonunun etkisini değerlendirmeyi amaçlamıştır. Gereç ve Yöntemler: Ortalama yaşı 36,3 \pm 7,6 yll olan (11 kadın, 8 erkek) her biri Miller Sinif I ve II DÇ'si olan 19 hasta seçildi. Kırk dört defekt, KPF ve bir SBDG kombinasyonu ile tedavi edildi. Dişeti çekilme derinliği (ÇD), dişeti çekilme genişliği (ÇG), sondllama derinliği (SD) ve klinik ataçman seviyesi (KAS) başlangıçta ve ameliyat sonrası 12. ayda kaydedildi. Bulgular: Başlangıçtan ameliyat sonrası 1 yıla kadar ortalama kök kapanmasl, maksiller DÇ'ler için \%89 ve mandibular GR'ler için \%68 idi. ÇD ve ÇG her iki grupta da başlangıçtan 12 aya azaldı $(p<0,001)$, ancak maksiller ve mandibular dişler arasinda istatistiksel olarak anlaml bir fark yoktu. Her iki tedavi de tatmin edici estetik sonuçlar gösterdi (RES, üst çene dişlerinde 8,2 $\pm 1,3$ ve alt çene dişlerinde 7,6 $\pm 1,1$ ). Sonuçlar: Bu çalışmanin bulguları, KPF'nin çoklu DÇ'lerin tedavisi için etkili bir prosedür olduğunu göstermiştir. Ayrıca, iki grup (Alt çene ve üst çene DÇ’leri), başlangıç değerinden 12 aya kadar değerlendirmelere benzer anlaml iyileşmeler gösterdi. Anahtar Kelimeler: Bă̆ dokusu, dişeti çekilmesi, cerrahi flepler, dis. 


\section{REFERENCES}

1. Wennström JL. Mucogingival therapy. Ann Periodontol 1996;1:671-701.

2. Armitage GC. Development of a classification system for periodontal diseases and conditions. Ann Periodontol 1999;4:1-6.

3. Serino G, Wennström JL, Lindhe J, Eneroth L. The prevalence and distribution of gingival recession in subjects with a high standard of oral hygiene. J Clin Periodontol 1994;21:57-63.

4. Chambrone L, Sukekava F, Araújo MG, Pustiglioni FE, Chambrone LA, Lima LA. Root-coverage procedures for the treatment of localized recession-type defects: A Cochrane systematic review. J Periodontol 2010;81:452-478.

5. Zucchelli G, Mounssif I. Periodontal plastic surgery. Periodontol 2000 2015;68:333-368.

6. Rajapakse PS, McCracken GI, Gwynnett E, Steen ND, Guentsch A, Heasman PA. Does tooth brushing influence the development and progression of noninflammatory gingival recession? A systematic review. J Clin Periodontol 2007;34:1046-1061.

7. Joss-Vassalli I, Grebenstein C, Topouzelis N, Sculean A, Katsaros C. Orthodontic therapy and gingival recession: a systematic review. Orthod Craniofac Res. 2010;13:127-141.

8. Gillette WB, Van House RL. Ill effects of improper oral hygeine procedure. J Am Dent Assoc 1980;101:476-480.

9. Chambrone L, Sukekava F, Araújo MG, Pustiglioni FE, Chambrone LA, Lima LA. Root-coverage procedures for the treatment of localized recession-type defects: a Cochrane systematic review. J Periodontol 2010;81:452-478.

10. Chambrone L, Tatakis DN. Periodontal soft tissue root coverage procedures: a systematic review from the AAP Regeneration Workshop. J Periodontol 2015;86:851.

11. Clauser C, Nieri M, Franceschi D, Pagliaro U, PiniPrato G. Evidence-based mucogingival therapy. Part 2: Ordinary and individual patient data meta-analyses of surgical treatment of recession using complete root coverage as the outcome variable. J Periodontol 2003;74:741-756.
12. Eren G, Atilla G. Platelet-rich fibrin in the treatment of localized gingival recessions: a split-mouth randomized clinical trial. Clin Oral Invest 2014;18:1941-1948.

13. Tonetti MS, Cortellini P, Pellegrini G, Nieri M. Xenogenic collagen matrix or autologous connective tissue graft as adjunct to coronally advanced flaps for coverage of multiple adjacent gingival recession: Randomized trial assessing non-inferiority in root coverage and superiority in oral health-related quality of life. 2018;45:78-88.

14. McGuire MK, Scheyer ET, Nunn M. Evaluation of human recession defects treated with coronally advanced flaps and either enamel matrix derivative or connective tissue: comparison of clinical parameters at 10 years. J Periodontol 2012;83:1353-1362.

15. Roccuzzo M, Bunino M, Needleman I, Sanz M. Periodontal plastic surgery for treatment of localized gingival recessions: a systematic review. J Clin Periodontol 2002;29:178-194; discussion 195-176.

16. Chambrone L, Chambrone D, Pustiglioni FE, Chambrone LA, Lima LA. Can subepithelial connective tissue grafts be considered the gold standard procedure in the treatment of Miller Class I and II recession-type defects? J Dent 2008;36:659-671.

17. Tatakis DN, Chambrone L, Allen EP, Langer B, McGuire MK, Richardson CR et al. Periodontal soft tissue root coverage procedures: a consensus report from the AAP Regeneration Workshop. J Periodontol 2015;86:52-55

18. Chambrone L. Clinical insights about the evolution of root coverage procedures: The flap, the graft, and the surgery. J Periodontol 2019;90:9-15.

19. Cairo F, Nieri M, Pagliaro U. Efficacy of periodontal plastic surgery procedures in the treatment of localized facial gingival recessions. A systematic review. J Clin Periodontol 2014;41:44-62.

20. Langer B, Langer L. Subepithelial connective tissue graft technique for root coverage. J Periodontol 1985;56:715-720.

21. Sculean A, Cosgarea R, Stahli A, Katsaros C, Arweiler NB, Miron RJ et al. Treatment of multiple adjacent maxillary Miller Class I, II, and III gingival recessions with the modified coronally advanced tunnel, 
enamel matrix derivative, and subepithelial connective tissue graft: a report of 12 cases. Quintessence Int 2016;47:653-659.

22. Graziani F, Gennai S, Roldán S, Discepoli N, Buti J, Madianos $\mathrm{P}$ et al Efficacy of periodontal plastic procedures in the treatment of multiple gingival recessions. J Clin Periodontol 2014;41:63-76.

23. Hofmänner $P$, Alessandri R, Laugisch $\mathrm{O}$, Aroca $\mathrm{S}$, Salvi GE, Stavropoulos A, Sculean A. Predictability of surgical techniques used for coverage of multiple adjacent gingival recessions-A systematic review. Quintessence Int 2012:545-554.

24. Pini Prato GP, Franceschi D, Cortellini P, Chambrone L. Long-term evaluation (20 years) of the outcomes of subepithelial connective tissue graft plus coronally advanced flap in the treatment of maxillary single recession-type defects. J Periodontol 2018;89:1290-1299.

25. Nart J, Valles C. Subepithelial Connective Tissue Graft in Combination with a Tunnel Technique for the Treatment of Miller Class II and III Gingival Recessions in Mandibular Incisors: Clinical and Esthetic Results. Int J Periodontics Restorative Dent

26. $2016 ; 36: 591-598$.

27. Pini Prato GP, Magnani C, Chambrone L. Long-term evaluation (20 years) of the outcomes of coronally advanced flap in the treatment of single recession-type defects. J Periodontol 2018;89:265-274.

28. Silness J, Loe H. Periodontal disease in pregnancy. ii. correlation between oral hygiene and periodontal condtion. Acta Odontol Scand. 1964;22:121-135.

29. Loe H, Silness J. Periodontal disease in pregnancy.

i. prevalence and severity. Acta Odontol Scand 1963;21:533-551.
30.Zucchelli G, Mele M, Mazzotti C, Marzadori M, Montebugnoli L, De Sanctis M. Coronally advanced flap with and without vertical releasing incisions for the treatment of multiple gingival recessions: a comparative controlled randomized clinical trial. J Periodontol 2009;80:1083-1094.

31. Bittencourt S, Del Peloso Ribeiro E, Sallum EA, Nociti FH, Jr., Casati MZ. Surgical microscope may enhance root coverage with subepithelial connective tissue graft: a randomized-controlled clinical trial. J Periodontol 2012;83:721-730.

32.Zucchelli G, De Sanctis M. Treatment of multiple recession-type defects in patients with esthetic demands. J Periodontol 2000;71:1506-1514.

33. da Silva RC, Joly JC, de Lima AF, Tatakis DN. Root coverage using the coronally positioned flap with or without a subepithelial connective tissue graft. J Periodontol 2004;75:413-419.

34. Jepsen K, Jepsen S, Zucchelli G, Stefanini M, de Sanctis M, Baldini $\mathrm{N}$ et al. Treatment of gingival recession defects with a coronally advanced flap and a xenogeneic collagen matrix: a multicenter randomized clinical trial. J Periodontol 2013;40:82-89.

35. de Sanctis M, Baldini N, Goracci C, Zucchelli G. Coronally advanced flap associated with a connective tissue graft for the treatment of multiple recession defects in mandibular posterior teeth. The International journal of periodontics \& restorative dentistry 2011;31:623-630.

36. Goldstein M, Boyan BD, Cochran DL, Schwartz Z. Human histology of new attachment after root coverage using subepithelial connective tissue graft. J Clin Periodontol 2001;28:657-662.

37. Mörmann W, Meier C, Firestone A. Gingival blood circulation after experimental wounds in man. J Clin Periodontol 1979;6:417-42. 